Cakrawala Dini: Jurnal Pendidikan Anak Usia Dini | p-ISSN 2087-I317 | e-ISSN 2621-8321

Vol. II. No.2 November 2020 | Hal I02-I0马

\title{
PENINGKATAN KOMPETENSI GURU PAUD DALAM PEMBELAJARAN TARI
}

\author{
Hayani Wulandari ${ }^{1}$, Tati Narawati ${ }^{2}$, Juju Masunah ${ }^{3}$, Mubiar Agustin ${ }^{4}$ \\ 1,2,3,4 Universitas Pendidikan Indonesia
}

\begin{abstract}
The purpose of this study is to provide an overview and understanding of the creative dance learning model for early childhood teachers through training on teacher competence in dance learning. This research is based on the competence of early childhood teachers, as well as a model of education and training as an effort to improve the ability of PAUD teachers. The method used in this research is the method of discussion, mentoring and training. The implementation of this training involved as many as 4 kindergarten teachers spread across several sub-districts in Purwakarta. After conducting the training, the teachers appear to be able to align aspects of development with the characteristics of early childhood, the teacher is able to apply play theory in learning, the teacher can make creative dance learning designs according to the curriculum, the teacher looks able to make assessment and evaluation reports of the learning he does, and teachers can apply it to students. The results of the evaluation of the implementation of this training can be seen from the direct application of creative dance learning by teachers to students. It is hoped that after this training, teachers can continue to apply creative dance learning to early childhood as an effort to manage learning that is interesting in optimizing the various potentials of children.
\end{abstract}

Keyword: Teacher competence, Dance lessons, Early Childhood

\begin{abstract}
Abstrak: Tujuan penelitian ini untuk memberikan gambaran dan pemahaman mengenai model pembelajaran tari kreatif kepada guru PAUD yang dilakukan melalui pelatihan kompetensi guru dalam pembelajaran tari. Penelitian ini berlandaskan pada kompetensi guru PAUD, serta model pendidikan dan pelatihan sebagai upaya meningkatkan kemampuan guru PAUD. Metode yang digunakan pada penelitian ini yaitu metode diskusi, pendampingan dan pelatihan. Pelaksanaan pelatihan ini melibatkan sebanyak 4 Guru TK yang tersebar pada beberapa kecamatan di Kabupaten Purwakarta. Setelah melakukan pelatihan, para guru terlihat mampu menyelaraskan antara aspek perkembangan dengan karakteristik anak usia dini, guru mampu mengaplikasikan teori bermain dalam pemelajaran, guru dapat membuat rancangan pembelajaran tari kreatif sesuai dengan kurikulum, guru terlihat mampu membuat laporan penilaian dan evaluasi dari pembelajaran yang dilakukannya, serta guru dapat mengaplikasikannya kepada peserta didik. Hasil evaluasi pelaksanaan pelatihan ini terlihat dari penerapan pembelajaran tari kreatif yang dilakukan guru kepada peserta didiknya secara langsung. Harapan setelah dilaksanakan pelatihan ini, guru-guru dapat terus menerapkan pembelajaran tari kreatif kepada anak usia dini sebagai upaya pengelolaan pembelajaran yang menarik dalam mengoptimalkan berbagai potensi yang dimiliki anak.
\end{abstract}

Kata Kunci: Kompetensi Guru, Pembelajaran Tari, Anak Usia Dini

\footnotetext{
'Universitas Pendidikan Indanesia, Email: hayaniwulandari国upi.edu

${ }^{2}$ Universitas Pendidikan Indanesia, Email: tnarawati国upi.edu

${ }^{3}$ Universitas Pendidikan Indonesia, Email: masunahjuju国upi.edu

${ }^{4}$ Universitas Pendidikan Indanesia, Email: mubiar国upi.edu
} 


\section{PENDAHULUAN}

Guru memiliki peranan yang penting dalam pelaksanaan pembelajaran terutama yang berkaitan dengan keberhasilan tercapainya tujuan pembelajaran. Menurut James W Born (M, 1986) mengemukakan bahwa tugas dan peranan guru dalam kegiatan pembelajaran meliputi mmengembangkan materi, merencanakan dan mempersiapkan kegiatan pembelajaran, serta mengevaluasi hasil pembelajaran yang dilakukan. Berdasarkan Undang-Undang No. 20 Tahun 2003 tentang Sistem Pendidikan Nasional pasal 3 bahwa tujuan pendidikan nasional yaitu mengembangkan potensi yang dimiliki peserta didik agar menjadi manusia yang berilmu dan bertaqwa kepada Tuhan Yang Maha Esa, berakal sehat, cakap, kreatif, mandiri dan menjadi warganegara yang demokratis serta tanggungjawab. Pernyataan tersebut menegaskan bahwa guru perlu memiliki keterampilan mengajar termasuk dalam mengelola kelas.

Pengelolaan kelas merupakan kegiatan yang dilakukan guru dalam menciptakan suasana belajar yang kondusif. Djamarah \& Zaini, (2002) mengungkapkan bahwa pengelolaan kelas merupakan salah satu tugas guru yang tidak boleh ditinggalkan, hal tersebut merupakan upaya untuk membentuk kelas yang kondusif sehingga kegiatan pembelajaran dapat berjalan dengan efektif. Tujuan dari pengelolaan kelas terbagi menjadi dua yang meliputi tujuan umum dan tujuan khusus. Tujuan umumnya yaitu untuk menyediakan dan menggunakan berbagai fasilitas dalam kegiatan belajar mengajar, sedangkan tujuan khususnya yaitu untuk mengembangkan dan mengoptimalkan berbagai kemampuan peserta didik melalui pemberdayaan fasilitas kegiatan belajar.

Berbagai aspek tumbuh kembang peserta didik perlu dioptimalkan termasuk kecerdasan majemuk. Terutama pada anak dengan rentang usia 5-6 tahun, karenanya mereka berada pada fase golden age (Bradecamp \& Rosengrant, 1992; Trenggonowati \& Kulsum, 2018; Uce, 2015) yang merupakan masa keemasan dimana setiap stimulus yang diberikan kepada anak sangat berpengaruh terhadap perkembangan dirinya. Selaras dengan yang diungkapkan

Mengingat pentingnya peran guru dalam pembelajaran, maka diperlukan guru yang profesional dan memiliki berbagai kompetensi yang dapat dikembangkan melalui program pelatihan dan pengembangan. Selaras dengan yang tertuang dalam Undang-Undang No. 14 Tahun 2005 pasal 32 tentang pengembangan profesi dan karir bahwa kompetensi-kompetensi yang perlu dikembangkan yaitu kompetensi pedagogik, kompetensi kepribadian, kompetensi sosial, dan kompetesi profesional. Penelitian ini berfokus pada pengembangan kometensi pedagogik dan kompetensi professional guru dalam kegiatan pembelajaran. Kompetensi pedagogik merupakan kompetensi dasar sebagai pembeda profesi guru dengan profesi yang lainnya. Kompetensi professional merupakan kompetensi yang berkaitan dengan penguasaan materi pembelajaran termasuk kurikulum, kemampuan mengelola pembelajaran, dan pengetahuan akan evaluasi. (Alma, 2010; Rusman, 2012)

Beberapa penelitian terkait, diantaranya yang dilakukan oleh Rochayadi, (2013) yang mengkaji upaya meningkatkan kompetensi guru PAUD melalui pedidikan dan pelatihan di Kecamatan Sukajadi Kota Bandung. Berdasarkan penelitian tersebut, pendidikan dan pelatihan merupakan salah satu alternatif dalam meningkatkan kompetensi guru. Penelitian lain yang dilakukan Maryani \& Septiani, (2019) berkaitan dengan pelatihan dan pendampingan bagi guru PAUD dalam 
mengeola kegiatan pembelajaran. Berdasarkan penelitian tersebut, melalui kegiatan pelatihan dan pendampingan terlihat dapat meningkatkan pengetahuan dan keterampilan guru terutama pada aspek pengelolaan kelas yang dapat diimplementasikan langsung oleh para guru sebagai peserta pelatihan, sehingga tercipta kegiatan pembelajaran yang menarik dan relevan dengan kehidupan siswa.

Kegiatan pembelajaran yang dimaksud pada penelitian ini yaitu pembelajaran tari yang merupakan salahsatu bidang ilmu yang dapat digunakan dalam mengembangkan potensi-potensi anak. Pada kenyataannya yang terjadi di lapangan dari hasil observasi peneliti, masih sedikit guruguru yang menerapkan pembelajaan tari pada kegiatan sehari-hari terutama mengenai tari kreatif. Beberapa guru terlihat menerapkan pembelajaran tari yang konvensional dengan menuntut anak untuk melakukan gerakan tari sesuai dengan yang guru lakukan.

Berdasarkan fenomena yang ada dan teori terkait akan pentingnya pengembangan kompetensi pedagogik dan kompetensi professional yang dimiliki guru dalam kegiatan pembelajaran tari, maka diperoleh rumusan masalah "bagaimana upaya meningkatkan kompetensi guru dalam pembelajaran tari ?" yang dilakukan melalui pelatihan dengan harapan kompetensi yang dimiliki guru PAUD terutama dalam aspek kompetensi pedagodik dan kompetensi profesional dapat dikembangkan dengan optimal sehingga akan berdampak pada kegiatan pembelajaran yang dilakukan kepada anak didiknya.

\section{METODOLOGI PENELITIAN}

Pelatihan ini dilakukan pada guru-guru TK yang tersebar pada beberapa kecamatan di Kabupaten Purwakarta. Kegitan ini melibatkan 4 guru dan 4 mahasiswa program studi
PGPAUD sebagai Co-trainer. Metode penelitian ini yaitu menggunakan metode diskusi, pendampingan dan pelatihan. Penelitian ini dilakukan selama 2 hari pada bulan Desember tahun 2019. Kegiatan yang dilakukannya yaitu penyampaian informasi dan diskusi mengenai pembelajaran di PAUD, pengoptimalan kecerdasan yang dimiliki anak, dan model pembeajaran tari kreatif. Pada tahapan pendampingan, guru melaksanakan pembelajaran tari kretaif dalam kelas mikro hingga akhirnya guru dapat menerapkan langsung kepada peserta didiknya masing-masing. Hal itulah yang menjadi tolak ukur keberhasilan dari pelaksanaan pelatihan/pembinaan. Hasil Penelitian ini dianalisis dan dideskripsikan secara kualitatif deskriptif.

\section{HASIL PENELITIAN DAN PEMBAHASAN}

Kegiatan ini dilakukan selama 2 hari pada bulan Desember tahun 2019. Peneliti bersama tim mengadakan pelatihan dan pendampingan terhadap 4 guru TK sebagai sampel yang ada di Kabupaten Purwakarta. Pelatihan dilakukan sebagai upaya memperkaya ilmu pengetahuan guru mengenai model pembelajaran tari kreatif dalam upaya mengembangkan kecerdasan majemuk anak usia dini sebagaimana yang diungkapkan Gardner, (1983) yang meliputi kecerdasan kinestetik, kecerdasan musikal, kecerdasan interpersonal, kecerdasan intrapersonal dan kecerdasan naturalis. Pendampingan dilakukan untuk memantau dan mengvaluasi hasil pelatihan yang guru terapkan langsung kepada peserta didiknya.

Kegiatan pelatihan dilakukan melalui model pembelajaran yang termasuk kedalam rumpun model interaksi sosial (social models) yang menitikberatkan pada kemampuan kerjasama dari para peserta didik. Melalui model ini, kemampuan setiap 
individu dapat ditingkatkan terutama dalam berhubungan dengan orang lain dengan proses belajar yang demokratis sehingga dapat belajar bersama masyarakat secara produktif. Model ini dipilih karena pada pelaksanaannya lebih mengarah kepada penyediaan informasi dan konsep pembelajaran yang menghubungkan antara individu dengan masyarakat. Seperti halnya pada pelaksanaan pelatihan ini yang dilakukan sebagai upaya menstimulus guru-guru dalam menerapkan model pembelajaran tari kreatif.

Beragam model-model pembelajaran yang tergolong kedalam rumpun model interaksi sosial diantaranya yaitu model daur pengalaman berstruktur dan analisis peran, model latihan penyelidikan (inquiry training model), dan model advance organizer. Upaya meningkatkan kompetensi guru PAUD dalam pembelajaran tari dilakukan peneliti melalui pelatihan yang kemas melalui model advance organizer yang dikembangkan oleh Ausebel sebagai model penerapan konsep melalui struktur kognititf. (Hanifah et al., 2014; Masnia, 2016)

Model Advance Organizer ini merupakan model dengan memberikan pengenalan materi terlebih dahulu yang kemudian dilanjutkan dengan pemberian tugas dengan tingkatan yang lebih tinggi. Terdapat tiga tahapan model pembelajaran advance organizer yaitu :

Tahapan Pertama (Presentasi Advance Organizer):

1. Mengklarifikasi tujuan-tujuan pembelajaran

2. Menyajikan organizer (Mengidentifikasi definisi ciri-ciri tertentu, Memberikan contoh, Mengulang)

3. Mendorong pengetahuan dan pengalaman siswa

Tedua (Presentasi tugas) :

1. Menyajikan materi

2. Mempertahankan perhatian

3. Memperjelas materi

4. Memperjelas pengolahan

Tahapan Ketiga (Memperkuat Struktu Kognitif) :

1. Menggunakan prinsip-prinsip rekonsiliasi integrative

2. Menganjurkan pembelajaran resepsi aktif.

3. Membangkitkan pendekatan kritis pada mata pelajaran.

4. Mengklarifikasi.

Model ini dipilih peneliti karena dianggap sesuai dengan tujuan dari penelitian yaitu menyampaikan perspektif baru bagi guru PAUD yang mengarah pada kompetensi pedagogik dan kompetensi professional. Berdasarkan tujuan tersebut, peneliti membuat 2 RPP sebagai acuan dalam pelaksanaan. RPP dibuat sebagai perencanaan pembelajaran untuk 
memudahkan peneliti dalam mencapai tujuan pembelajaran. Selaras dengan yang diungkapkan Masitoh dkk, (2005, hlm. 136) bahwa perencaaan pembelajaran merupakan sebuah dasar hingga terciptanya suatu kondisi pembelajaran yang efektif. RPP yang pertama mengarah kepada kompetensi pedagogik guru PAUD dengan tujuan agar guru-guru PAUD memiliki pengetahuan dan keterampilan mengenai pembelajaran tari kreatif sehingga para guru dapat: 1) Mengorganisasikan aspek perkembangan sesuai dengan karakteristik anak usia dini; 2)
Menganalisis teori bermain sesuai aspek dan tahapan perkembangan, kebutuhan, potensi, bakat, dan minat anak usia dini; 3) Merancang kegiatan pengembangan anak usia dini berdasarkan kurikulum; 4) Mengembangkan potensi anak usia dini untuk pengaktualisasian diri; 5) Menyelenggarakan dan membuat laporan penilaian, evaluasi proses dan hasil belajar anak usia dini; dan 6) Menentukan lingkup sasaran asesmen proses dan hasil pembelajaran pada anak usia dini. Pelaksanaan pelatihannya dilakukan sebagai berikut:

\section{Tahapan Pertama (Presentasi Advance Organizer):}

- Guru mengucapkan salam

- Guru mengecek kehadiran peserta

- Guru menuliskan judul materi pelatihan

- Guru menyampaikan tujuan pelatihan

- Guru menyajikan advance organizer dengan memberikan penjelasan istilahistilah penting yang terdapat didalam bahan kajian pelatihan

- Guru memberikan rangsangan pengetahuan dan pengalaman peserta yang sudah ada dan disesuaikan dengan konteks yang diajarkan.

Tahapan Kedua (Presentasi tugas) :

- Guru meminta peserta ikut serta dalam kegiatan simulasi berhubungan dengan materi

- Guru memberikan materi menggunakan power point

- Guru meminta peserta mengulang materi tentang Karakteristik Anak Usia Dini Teori Bermain

- Guru membagi peserta menjadi beberapa kelompok, membagikan lembar diskusi dan meminta peserta mengerjakan lembar diskusi tersebut

- Guru meminta peserta mempresentasikan hasil diskusinya

Tahapan Ketiga (Memperkuat Struktu Kognitif) :

Guru melakukan sesi tanya jawab dengan peserta

Guru melakukan pengembangan pembelajaran secara aktif

Guru membimbing peserta menarik kesimpulan berdasarkan tujuan pembelajaran

RPP yang kedua berkaitan dengan kompetensi professional guru PAUD. Tujuan pada pertemuan kedua yaitu untuk : 1) Mengembangkan materi, struktur, dan konsep bidang keilmuan yang mendukung serta sejalan dengan 
kebutuhan dan tahapan perkembangan anak usia dini; 2) Merancang berbagai kegiatan pengembangan secara kreatif sesuai dengan tahapan perkembangan anak usia dini; dan 3) Mengembangkan keprofesionalan secara berkelanjutan dengan melakukan tindakan reflektif. Pelaksanaannya dilakukan sebagai berikut:

\section{Tahapan Pertama (Presentasi Advance Organizer):}

- Guru mengucapkan salam

- Guru mengecek kehadiran peserta

- Guru menuliskan judul materi pelatihan

- Guru menyampaikan tujuan pelatihan

- Guru menyajikan advance organizer dengan memberikan penjelasan mengenai unsur tari stimulus pembelajaran.

- Guru memberikan rangsangan pengetahuan dan pengalaman peserta dalam melakukan pemahaman gerak mengenai unsur tari dan stimulus pembelajaran.

\section{Tahapan Kedua (Presentasi tugas) :}

- Guru meminta peserta ikut serta dalam kegiatan simulasi berhubungan dengan materi

- Guru memberikan materi menggunakan power point

- Guru meminta peserta mengikuti gerak yang dilakuan guru untuk melakukan beberapa gerak dasar dan unsur dalam tari

- Guru membagi peserta menjadi beberapa kelompok, berdiskusi mengenai gerak dasar dan unsur dalam tari.

- Guru meminta peserta mempresentasikan hasil diskusinya

Tahapan Ketiga (Memperkuat Struktu Kognitif) :

- Guru melakukan sesi tanya jawab dengan peserta

- Guru melakukan pengembangan pembelajaran secara aktif

Guru membimbing peserta menarik kesimpulan berdasarkan tujuan pembelajaran

Berdasarkan RPP tersebut, pada pelaksanaannya diperoleh hasil yang baik terlihat dari keefektifan pelaksanaan pelatihan. Guru-guru yang mengikuti pelatihan terlihat mampu mengikuti kegiatan dengan tertib serta ilmu yang didapat disaat pelatihan terlihat mampu diterapkannya pada pembelajaran mikro hingga akhirnya mampu diterapkan pada peserta didik di sekolahnya masing- masing. Seperti yang terlihat pada gambar berikut ini:

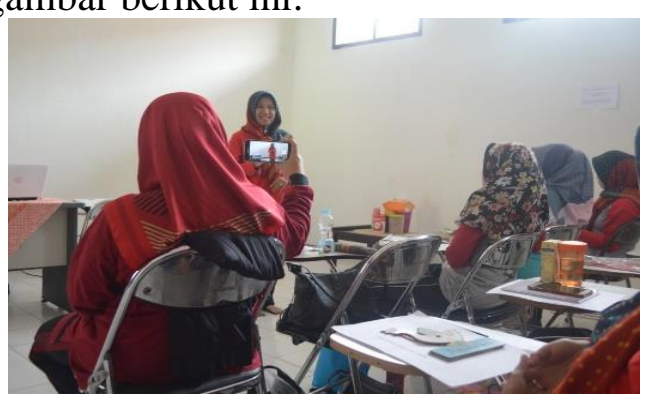


Gambar 1. Pelaksanaan Pelatihan Guru (Sumber : Dokumentasi Pribadi)

Setelah melakukan pelatihan, dilihat dari kompetensi pedagogik yang dimiliki, guru terlihat mampu menyelaraskan antara aspek perkembangan dengan karakteristik anak usia dini, guru mampu mengaplikasikan teori bermain dalam mengoptimalkan aspek perkembangan anak usia dini dengan merujuk pada potensi minat dan bakat anak, guru dapat membuat rancangan pembelajaran tari kreatif sesuai dengan kurikulum 2013, guru terlihat mampu membuat laporan penilaian dan evaluasi dari pembelajaran yang dilakukannya. Apabila dilihat dari kompetensi professionalnya, guru sudah mampu melaksanakan pembelajaran tari kreatif sesuai dengan karakteristik dan tahapan usia anak secara berkelanjutan. Terlihat dari proses pelaksanaan pembelajaran mikro sebagai berikut:

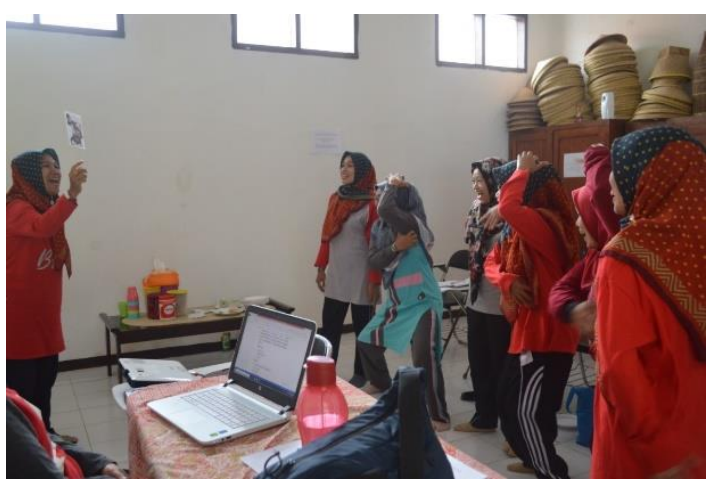

Gambar 2. Proses Pembelajaran Mikro

(Sumber : Dokumentasi Pribadi)

Keefektifan

pelaksanaan

pelatihan menjadikan kegiatan tersebut perlu untuk terus dikembangkan dan tetap dilakukan secara berkesinambuangan. Selaras dengan yang dilakukan Ndeot \& Palmin, (2013) bahwa kompetensi-kompetensi yang dimiliki guru terutama dalam mengatasi kurangnya pemahaman guru maka perlu dilakukan kegiatan PKG (Pelatihan Kompetensi Guru) secara berkesinambungan.

\section{KESIMPULAN}

Pengembangan kompetensi yang dimiliki guru sangat penting dilakukan termasuk pada pengembangan kompetensi pedagogik dan kompetensi professional. Hal tersebut dilakukan guna menciptakan kegiatan pembelajaran yang efektif sehingga berdampak pada peserta didik. Model pembelajaran advance organizer dapat dipilih menjadi salah satu solusi dalam upaya pengembangan kompetensi yang dimiliki guru. Melalui model pembelajaran advance organizer ini bukan hanya dapat mengembangkan pengetahuan yang dimiliki guru, akan tetapi dapat meningkatkan keterampilan guru mengenai pengelolaan pembelajaran terutama yang menjadi fokus pada penelitian ini yaitu yang berkaitan dengan penerapan pembelajaran tari kreatif terhadap kecerdasan majemuk anak usia dini. Keefektifan penerapan model advance organizer ini terlihat ketika guru mampu mengaplikasikan hasil dari pengetahuan dan keterampilan mengenai pembelajaran tari kreatif yang didapat dari pelatihan pada pembelajaran mikro yang kemudian diaplikasikan juga oleh para guru kepada peserta didiknya.

\section{DAFTAR PUSTAKA}

Alma, B. (2010). Guru Profesional Menguasai Metode dan Terampil Mengajar. Alfabeta.

Bradecamp, S., \& Rosengrant, T. (1992). Appropiable curriculum and assesment for young children. NAEYC.

Djamarah, S. B., \& Zaini, A. (2002). Strategi Belajar Mengajar. PT. Rineka Cipta.

Gardner, H. (1983). Frames of minds: Multiple Intelligence.

Hanifah, F., Karyati, D., \& Komalasari., H. (2014). Aplikasi Model Adance Organizer pada Pembelajaran Seni Tari untuk Meningkatkan Kognitif Siswa di SMP Negeri 30 Bandung. 1-20. 
M, S. A. (1986). Interaksi dan Motivasi Belajar Mengajar. CV. Rajawali.

Maryani, I., \& Septiani, P. D. (2019). Pelatihan dan pendampingan pengelolaan kelas berbasis gaya belajar bagi guru PAUD dan TK di Desa Muntuk, Dlingo , Bantul , Yogyakarta. Publikasi Hasil Pengabdian Kepada Masyarakat, 3(1), 103-110. http://journal2.uad.ac.id/index.ph p/jpmuad/article/view/594/pdf

Masitoh, \& Dkk. (2005). Pendekatan Pembelajaran Aktif di Taman Kanak- Kanak. Departemen Pendidikan Nasional.

Masnia, M. (2016). Penerapan Model Pembelajaran Investigasi Kelompok Untuk Meningkatkan Hasil Belajar Siswa. APOTEMA : Jurnal Program Studi Pendidikan Matematika, 2(2), 45-51. https://doi.org/10.31597/ja.v2i2.1

16

Ndeot, F., \& Palmin, B. (2013). Pelatihan menyusun rencana pembelajaran bagi guru paud di pkg cibal dan cibal barat.

Rochayadi, I. (2013). Upaya Meningkatkan Kompetensi Guru Paud Melalui Pendidikan Dan Pelatihan Guru Di Paud Bougenville Kecamatan Sukajadi Kota Bandung. Journal of Chemical Information and Modeling, 53(9), 1689-1699. https://doi.org/10.1017/CBO9781 107415324.004

Rusman. (2012). Model-Model Pembelajaran Mengembangkana Profesionalisme Guru. PT Rajagrafindo Persada.

Trenggonowati, D. L., \& Kulsum. (2018). Analisis Faktor Optimalisasi Golden Age Anak Usia. 4 (1), 48-56.

Uce, L. (2015). The Golden Age: Masa Efektif Merancang Kualitas Anak. Jurnal Pendidikan Anak BUnayya, 1 (2), 27-63. https://doi.org/10.4324/97804290 50770-2 